\title{
A Hospital Based Cross-sectional Study on Demographic Distribution of Both Symptomatic and Asymptomatic Patients an Art at Westren Region of Rajasthan.
}

\author{
Alok Gahlot ${ }^{1}$, Pooja Gahlot ${ }^{2}$, Jitendra Acharya ${ }^{3}$ \\ ${ }^{1}$ (M.D. Medicine) Senior Resident Department Of Medicine P.D.U. Medical College Churu, ${ }^{2}$ M.S. Gynae \&Obs., Assistant Professor Department Of Gyne \& \\ Obs. P.D.U Medical College Churu, ${ }^{3}$ S.P. Medical College Bikaner.
}

\section{Abstract}

Background: Over the past two decades with the advent of highly active antiretroviral therapy (HAART), there is a substantial increase in the life span of HIV patients. Morbidity and mortality due to human immunodeficiency virus (HIV) continue to be major problems in developing countries like India. Subjects and Methods: The present study was a cross sectional hospital based study for a period of twelve months from 1st Nov. 2015 to 31 st Oct. 2016 at ART center P.B.M. Hospital, Bikaner. 100 HIV+ patients on ART were included in the study by consecutive sampling technique. Results: We found that Maximum number of study participants in age group of 31-40 years in both study $(50 \%)$ and control (42\%) group. Males were higher in study (76\%) as well as control (64\%) group than females .Among the subjects mostly belonged to lower socioeconomic status followed by Medium and High socioeconomic status. Most of the subjects in study (92\%) as well as control (94\%) groups were married. Conclusion: We conclude that Males were higher in study (76\%) as well as control (64\%) group than females .Among the subjects mostly belonged to lower socioeconomic status followed by Medium and High socioeconomic status.

Keywords: Haart, Hiv, Morbidity, Mortality.

Corresponding Author: Dr. Pooja Gahlot, M.S. Gynae \& Obs., Assistant Professor Department Of Gyne \& Obs. P.D.U Medical College Churu.

Received: October 2019

Accepted: October 2019

\section{Introduction}

Over the past two decades with the advent of highly active antiretroviral therapy (HAART), there is a substantial increase in the life span of HIV patients. Hence, the focus has now shifted to managing long-term complications of HIV infection and improving the quality of life of HIV patients, especially in developed nations. On the other hand, in developing nations, the ever-growing incidence of HIV infection has placed a huge burden on their frail economy, so there is a growing need for simplifying HIV treatment protocols and for having cheaper alternatives for monitoring disease activity. ${ }^{[1]}$

Morbidity and mortality due to human immunodeficiency virus (HIV) continue to be major problems in developing countries like India. Currently, the availability and affordability of antiretroviral treatment (ART) are improving in these countries. ${ }^{[2]}$ Though CD4-positive (CD4+) T-cell estimation and the plasma HIV-1 load continue to be the major prognostic markers of progression, several other peripheral blood constituents may be considered for roles as prognostic markers. ${ }^{[3,4,5]}$

\section{Subjects and Methods}

The present study was a cross sectional hospital based study for a period of twelve months from 1st Nov. 2015 to 31st Oct. 2016 at ART center P.B.M. Hospital, Bikaner.

\section{Sample Size and Sampling Technique:}

100 HIV+ patients on ART were included in the study by consecutive sampling technique. Out of 100 patients, 50 were symptomatic and included in study group and remaining 50 were asymptomatic and taken as controls.

\section{Inclusion Criteria-}

1. Age more than 18 years

2. ii. Patients sero positive for HIV-antibodies

3. iii. Patients on ART at least 6 months

4. iv. Ready to give consent.

5.

\section{Exclusion Criteria}

Patients below age of 18 years.

Patients who were known case of rheumatoid arthritis, connective tissue disorders and cancers.

Patients with pre existing liver, kidney and heart disease. 


\section{Asymptamatic Patients an Art at Western Regian of Rajasthan}

HIV positive patients on ART were enrolled for the study with their informed consent. All the patients were tested for the HIV antibodies at the ICTC P.B.M .Hospital Bikaner.

\section{Data Analysis}

The information thus collected was entered into excel sheet and analyzed with the help of SPSS 22.0 in form of frequencies, mean, SD, correlation and appropriate test of significance, considering $\mathrm{p}=0.05$ as cut off level of significance.

\section{Results}

We found that shows maximum number of participants in age group of $31-40$ years in both study $(50 \%)$ and control (42\%) group.[Table 1] The subjects according to gender, males were higher in study $(76 \%)$ as well as control $(64 \%)$ group than females and there was no statistical significant difference between both the groups.[Table 2] Maximum number of subjects was from Bikaner with $74 \%$ of subjects in cases and $64 \%$ in controls. There was no statistical significant difference between cases and controls by residence. [Table 3] Among the subjects mostly belonged to lower socioeconomic status followed by Medium and High socioeconomic status. There was no statistical significant difference between cases and controls by socioeconomic status [Table 4]. Distribution of subjects by Marital Status. Most of the subjects in study (92\%) as well as control (94\%) were married and the difference between marital statuses in both the groups was found to be statistically not significant.[Table 5]

\begin{tabular}{|l|l|l|l|}
\hline Table 1: Distribution of subjects according to Age Group \\
\hline $\begin{array}{l}\text { Age Group (in } \\
\text { years) }\end{array}$ & \multicolumn{2}{|l|}{ Group } & \multirow{2}{*}{ P value } \\
\cline { 2 - 3 } & Study & Control & \\
\hline $18-30$ & $11(22 \%)$ & $13(26 \%)$ & \multirow{2}{*}{$\chi^{2}=1.184$} \\
\hline $31-40$ & $25(50 \%)$ & $21(42 \%)$ & \multirow{2}{*}{0.667 (Not } \\
\hline $41-50$ & $7(14 \%)$ & $10(20 \%)$ & Significant) \\
\hline $51-60$ & $4(8 \%)$ & $3(6 \%)$ & \\
\hline$>60$ & $3(6 \%)$ & $3(6 \%)$ & \\
\hline Total & $50(100 \%)$ & $50(100 \%)$ & \\
\hline
\end{tabular}

Table 2: Distribution of subjects by Gender

\begin{tabular}{|l|l|l|}
\hline \multirow{2}{*}{ Gender } & Group \\
\cline { 2 - 3 } & Study & Control \\
\hline Male & $38(76 \%)$ & $32(64 \%)$ \\
\hline Female & $12(24 \%)$ & $18(36 \%)$ \\
\hline Total & $50(100 \%)$ & $50(100 \%)$ \\
\hline P value & 0.190 & \\
\hline
\end{tabular}

\begin{tabular}{l}
\hline Table 3: Distribution of subjects according to Residence \\
\begin{tabular}{|l|l|l|l|}
\hline \multirow{2}{*}{ Residence } & Group & & \\
\cline { 2 - 3 } & Study & Control & \\
\hline Churu & $4(8 \%)$ & $8(16 \%)$ & \multirow{3}{*}{ P value $=0.257$} \\
\hline Bikaner & $37(74 \%)$ & $32(64 \%)$ & \\
\hline Hanumangarh & $4(8 \%)$ & $2(4 \%)$ & \\
\hline Sri Ganganagar & $2(4 \%)$ & $7(14 \%)$ & \\
\hline Others & $3(6 \%)$ & $1(2 \%)$ & \\
\hline
\end{tabular}
\end{tabular}

Table 4: Distribution of subjects by Socioeconomic Status

\begin{tabular}{|l|l|l|l|}
\hline \multirow{2}{*}{ SES } & Group & P value \\
\cline { 2 - 3 } & Study & Control & \\
\hline Low & $34(68 \%)$ & $35(70 \%)$ & 0.976 \\
Medium & $15(30 \%)$ & $14(28 \%)$ & (Not Significant) \\
\hline High & $1(2 \%)$ & $1(2 \%)$ & \\
\hline Total & $50(100 \%)$ & $50(100 \%)$ & \\
\hline
\end{tabular}

Table 5: Distribution of subjects by Marital Status

\begin{tabular}{|l|l|l|l|}
\hline \multirow{2}{*}{ Marital status } & Group & P value \\
\cline { 2 - 3 } & Study & Control & \\
\hline Married & $46(92 \%)$ & $47(94 \%)$ & 0.695 \\
\hline Unmarried & $4(8 \%)$ & $3(6 \%)$ & \multirow{2}{*}{ (Not Significant) } \\
\hline Total & $50(100 \%)$ & $50(100 \%)$ & \\
\hline
\end{tabular}

\section{Discussion}

Maximum number of study participants in age group of 3140 years in both study $(50 \%)$ and control $(42 \%)$ group and this matches with National AIDS Control Organization Technical Report66 data, 2015 estimation that adult 15+ population contributed to almost half of PLHIVs.

Males were higher in study $(76 \%)$ as well as control $(64 \%)$ group than females as this disease affects males more because of heterosexual nature. Similar proportion is reported by NACO66, as females in PLHIV group being 40.5\%.Maximum number of study subjects was from Bikaner with $74 \%$ of subjects in cases and $64 \%$ in controls. This is because study was carried out at ART centre attached to PBM Hospital, Bikaner.

Among the subjects mostly belonged to lower socioeconomic status followed by Medium and High socioeconomic status, this may be contributed to higher education status and more awareness among medium and high socio economic class patients. Most of the subjects in study (92\%) as well as control (94\%) were married. As per National AIDS Control Organization (NACO) $(2015)^{6}$, government of India report estimated that The total number of people living with HIV (PLHIV) in India is estimated at 21.17 lakhs (17.11 lakhs26.49 lakhs) in 2015 compared with 22.26 lakhs (18.00 lakhs-27.85 lakhs) in 2007. Children ( $<15$ years) account for $6.54 \%$, while two fifth $(40.5 \%)$ of total HIV infections are among females. Vishwanath A et al $(2016)^{7}$ observed in their study on acute phase C-reactive protein (CRP) levels in human immunodeficiency virus (HIV) infection that the relationship of CRP with HIV was assessed in 119 HIVpositive patients and correlated with CD4 counts and mortality at $1 \mathrm{y}$. CRP was negatively correlated with CD4 counts with levels of CRP being highest in the group with CD4 counts below 200 cells $/ \mu \mathrm{L} .{ }^{8}$ It was an indicator of mortality and hence may serve as a useful and inexpensive predictor of HIV disease progression.

\section{Conclusion}

We conclude that

1. Maximum number of study participants in age group of $31-40$ years in both study $(50 \%)$ and control (42\%) group.

2. Males were higher in study $(76 \%)$ as well as control 


\section{Asymptamatic Patients an Art at Western Regian of Rajasthan}

(64\%) group than females.

3. Maximum number of study subjects was from Bikaner with $74 \%$ of subjects in cases and $64 \%$ in controls.

4. Among the subjects mostly belonged to lower socioeconomic status followed by Medium and High socioeconomic status.

5. Most of the subjects in study (92\%) as well as control (94\%) groups was married.

6. Mean duration since first diagnosed was higher in control group than study group and this difference was found to be statistically not significant.

\section{References}

1. Joint United Nations Program on HIV/AIDS. 14 January 2007 accession date. AIDS epidemic update: December 2005. http://www.unaids.org/epi/2005.

2. WHO. 14 January 2007 accession date. Progress on global access to HIV antiretroviral therapy: an update on "3 by 5." http://www.who.int/3by5/june2005execsummary.pdf.
3. Arinola, O. G., K. S. Adedapo, A. O. Kehinde, J. A. Olaniyi, and M. O. Akiibinu. 2004. Acute phase proteins, trace elements in asymptomatic human immunodeficiency virus infection in Nigerians. Afr. J. Med. Med. Sci. 33:317-322.

4. Feldman, J. G., D. N. Burns, S. J. Gange, P. Bacchetti, M. Cohen, K. Anastos, M. Nowicki, R. Delapena, and P. Miotti. 2000. Serum albumin as a predictor of survival in HIV-infected women in the Women's Interagency HIV Study. AIDS14:863-870.

5. Feldman, J. G., P. Goldwasser, S. Holman, J. DeHovitz, and H. Minkoff. 2003. C-reactive protein is an independent predictor of mortality in women with HIV-1 infection. J. Acquir. Immune Defic. Syndr. 32:210-214.

6. India HIV Estimations 2015 Technical Report. National AIDS Control Organization \& National Institute of Medical Statistics, ICMR. MoHFW, Government of India.

7. Vishwanath A, Quaiser S, Khan R. Role of high-sensitivity C-reactive protein measurements in HIV patients. Indian J Sex Transm Dis [serial online] 2016 [cited 2016 Dec 30];37:123-8. Available from: http://www.ijstd.org/text.asp?2016/37/2/123/192127

8. Ugwu MC. Human serum protein and C-Reactive Protein levels among HIV infected subjects in uromi and its environs in Edo, Nigeria. IJBAIR, 2016, 5(3): 74-80.

Copyright: (C) the author(s), 2019. It is an open-access article distributed under the terms of the Creative Commons Attribution License (CC BY 4.0), which permits authors to retain ownership of the copyright for their content, and allow anyone to download, reuse, reprint, modify, distribute and/or copy the content as long as the original authors and source are cited.

How to cite this article: Gahlot A, Gahlot P, Acharya J. A Hospital Based Cross-sectional Study on Demographic Distribution of Both Symptomatic and Asymptomatic Patients an Art at Westren Region of Rajasthan..Acad. J Med. 2019;2(2):11-13.

DOI: dx.doi.org/10.21276/ajm.2019.2.2.4

Source of Support: Nil, Conflict of Interest: None declared. 